\title{
Ceramide inhibition of chondrocyte proliferation and bone growth is IGF-I independent
}

\author{
V E MacRae ${ }^{1,2}$, T Burdon', S F Ahmed ${ }^{2}$ and C Farquharson ${ }^{1}$ \\ ${ }^{1}$ Bone Biology Group, Division of Gene Function and Development, Roslin Institute, Roslin, Midlothian EH25 9PS, UK \\ ${ }^{2}$ Bone and Endocrine Research Group, Royal Hospital for Sick Children, Glasgow, UK \\ (Requests for offprints should be addressed to V E MacRae; Email: vicky.macrae@bbsrc.ac.uk)
}

\begin{abstract}
Proinflammatory cytokines inhibit growth plate development. However, their underlying mechanisms of action are unclear. These effects may be mediated by ceramide, a sphingosine-based lipid second messenger, which is elevated in a number of chronic inflammatory diseases. To test this hypothesis, we determined the effects of $\mathrm{C} 2$-ceramide, a cell permeable ceramide analogue, on the growth of the ATDC5 chondrogenic cell line and on cultured fetal mice metatarsals. In ATDC 5 cells, C2-ceramide significantly induced apoptosis at both $40(82 \% ; P<0 \cdot 05)$ and $25 \mu \mathrm{M}(53 \% ; P<0 \cdot 05)$. At $40 \mu \mathrm{M}, \mathrm{C} 2$-ceramide significantly reduced proliferation $\left(\left[{ }^{3} \mathrm{H}\right]\right.$-thymidine uptake/mg protein) $(62 \% ; P<0 \cdot 05)$. C2ceramide did not markedly alter the differentiation state of the cells as judged by the expression of markers of chondrogenesis and differentiation (sox 9, collagen II and collagen X). The IGF-I signalling pathway is the major autocrine/paracrine regulator of bone growth. Both in the presence and absence
\end{abstract}

of IGF-I, C2-ceramide $(25 \mu \mathrm{M})$ induced an equivalent reduction in proliferation $(60 \% ; P<0 \cdot 001)$. Similarly, C2ceramide $(40 \mu \mathrm{M})$ induced a $31 \%$ reduction in fetal metatarsal growth both in the presence and absence of IGF-I (both $P<0 \cdot 001)$. Furthermore, C2-ceramide reduced ADCT5 proliferation in the presence of AG1024, an IGF-I and insulin receptor blocker. Therefore, C2-ceramide-dependent inhibition appears to be independent of IGF-mediated stimulation of bone growth. Indeed, biochemical studies demonstrated that $\mathrm{C} 2$-ceramide $(25 \mu \mathrm{M})$ pretreatment did not alter IGF-I-stimulated phosphorylation of insulin receptor substrate-1, Akt or P44/42 MAP kinase. In conclusion, C2-ceramide inhibits proliferation and induces apoptosis in growth plate chondrocytes through an IGF-I independent mechanism.

Journal of Endocrinology (2006) 191, 369-377

\section{Introduction}

Chronic inflammatory diseases such as juvenile idiopathic arthritis and inflammatory bowel disease often lead to childhood growth retardation through a number of proposed mechanisms that includes nutritional deficiency, chronic inflammation, increased catabolism, defects in the growth hormone (GH)/insulin-like growth factor-I (IGF-I) axis and use of glucocorticoids (MacRae et al. 2006a, Wong et al. 2006). Levels of proinflammatory cytokines, such as tumour necrosis factor (TNF) $\alpha$ and interleukin (IL) $-1 \beta$ are often raised in these diseases, and measures that block TNF- $\alpha$ action, such as anti-TNF therapy, lead to an improvement in growth. This effect has been reported to be independent of the concurrent reduction in growth associated with glucocorticoid therapy (Tynjala et al. 2006). TNF- $\alpha$ and IL-1 $\beta$ may directly inhibit growth plate chondrocyte dynamics as well as longitudinal growth in vitro (Martensson et al. 2004, MacRae et al. 2006b), however, the underlying mechanisms that lead to these effects are unclear.
The IGF-I signalling pathway is the major autocrine/paracrine regulator of bone growth (Loveridge et al. 1990). Binding of IGF-I to its receptor utilises a family of soluble receptors, known as insulin receptor substrates (IRSs), to initiate a series of autophosphorylation events. This results in the activation of two distinct signalling pathways, phosphatidylinositol 3-kinase (PI-3K) and $\mathrm{p} 44 / \mathrm{p} 42$ mitogen-activated protein kinase (MAPK), leading to pro-proliferative and anti-apoptotic effects.

In many cell types, signal transduction of IL- $1 \beta$ and TNF- $\alpha$ involves the activation of neutral (N) and acidic (A) sphingomyelinase (SMase) pathways, which catalyse the degradation of the membrane phospholipid sphingomyelin into phosphocholine and ceramide (Mathias et al. 1993, Wiegmann et al. 1994, Rybakina et al. 2001). Ceramide levels are also elevated through a de novo synthesis pathway following activation of IL- $1 \beta$ and TNF- $\alpha$ receptors (Memon et al. 1998, Xu et al. 1998). Ceramide has been shown to inhibit IGF-Iinduced tyrosine phosphorylation of IRS-1 in myoblast and hepatic cells (Kanety et al. 1996, Strle et al. 2004). Ceramide has also been shown to induce apoptosis in a wide range of different 
cell types, including pancreatic $\beta$-cells (Sjoholm 1995), cardiomyocytes (de Vries et al. 1997) and astrocytes (Oh et al. 2006). Furthermore, ceramide has been shown to induce apoptosis, proteoglycan degradation and matrix metalloproteinase expression in articular chondrocytes (Sabatini et al. 2000, Gilbert et al. 2004, 2006).

Whilst previous studies have shown that IL- $1 \beta$ and TNF $\alpha$ inhibit growth plate chondrocyte differentiation and induce cell death (Martensson et al. 2004, MacRae et al. 2006b), the direct effects of ceramide on growth plate chondrocytes have yet to be reported. In this study, the ATDC5 chondrogenic cell line was used to characterise and compare the effects of ceramide on cell proliferation, differentiation and apoptosis. Subsequently, the effect of ceramide on IGF-I signalling was examined using ATDC5 cells and the fetal murine metatarsal model.

\section{Materials and Methods}

\section{Chondrocyte cell culture}

The ATDC5 chondrocyte cell line was sourced from the RIKEN cell bank (Ibaraki, Japan) and maintained as described by Atsumi et al. (1990). Cells were maintained in T175 tissue culture flasks (Greiner Bio-One $\mathrm{GmbH}$, Frickenhausen, Baden-Württemberg, Germany) at a density of 250000 cells/flask in a maintenance medium of Dulbecco's Modified Eagle Medium (DMEM)/Ham's F12 (Invitrogen) supplemented with $5 \%$ FCS (Invitrogen), $10 \mu \mathrm{g} / \mathrm{ml}$ human transferrin, $3 \times 10^{-8} \mathrm{M}$ sodium selenite (Sigma), sodium pyruvate $(1 \mathrm{mM}$; Invitrogen) and gentamycin $(50 \mu \mathrm{g} / \mathrm{ml}$, Invitrogen). For individual experiments semi-confluent cultures were passaged with trypsin-EDTA (Sigma) and cultured (day 0 ) at a density of $6000 \mathrm{cells} / \mathrm{cm}^{2}$ in multi-well plates (Costar, High Wycombe, Bucks, UK) in a differentiation medium that consisted of maintenance medium supplemented with insulin $\left(10 \mu \mathrm{g} / \mathrm{ml}\right.$; Sigma). Incubation was at $37{ }^{\circ} \mathrm{C}$ in a humidified atmosphere of $95 \%$ air $/ 5 \% \mathrm{CO}_{2}$ and the medium was changed every second or third day. In all experiments, unless otherwise stated, C2-ceramide (Sigma), a cell permeable ceramide analogue, was added to chondrocyte cultures on day 6 , at a final concentration of 40,25 and $10 \mu \mathrm{M}$. The diluent for C2-ceramide was ethanol (final concentration 0.1\%). All control cultures received $0 \cdot 1 \%$ ethanol only.

ATDC5 cells were deprived of serum and insulin/transferrin/selenium for $18 \mathrm{~h}$ before the initiation of treatments in the presence of IGF-I $(100 \mathrm{ng} / \mathrm{ml}$; Bachem, UK Ltd, St Helens, Merseyside, UK), AG1024 (Sigma) and before the initiation of the cell-signalling studies.

\section{Ceramide mechanisms associated with proinflammatory cytokine exposure}

D609 (10 $\mu \mathrm{g} / \mathrm{ml}$; Sigma), an inhibitor of A-SMase activity, was added to cells cultured in 48 well plates, in the presence of IL- $1 \beta$ and TNF- $\alpha$ (both $10 \mathrm{ng} / \mathrm{ml})$. The rate of chondrocyte proliferation was assessed over a $24 \mathrm{~h}$ period starting on day 6 . On day 7 , the chondrocytes were incubated with $0 \cdot 2 \mu \mathrm{Ci} / \mathrm{ml}$ $\left[{ }^{3} \mathrm{H}\right]$ thymidine $(37 \mathrm{MBq} / \mathrm{ml}$; Amersham Pharmacia Biotech) for the last $2 \mathrm{~h}$ of the culture period. The amount of radioactivity incorporated into trichloroacetic acid-insoluble precipitates was measured (Farquharson et al. 1999).

\section{Chondrocyte number, proliferation and apoptosis}

Proliferation was determined over a $24 \mathrm{~h}$ period starting on day 6, as described above. Protein content of the trichloroaceticacid-insoluble precipitates was determined as a measure of cell number. Protein content was measured using the BioRad DC protein assay (Bio-Rad Laboratories, Inc.) based on the Bradford dye-binding procedure and $\gamma$-globulin as standard (Farquharson et al. 1995). Apoptosis of the cells was measured using the APO Percentage Apoptosis assay (Biocolor Ltd, Belfast, Northern Ireland), which quantifies dye uptake by apoptotic cells only after the translocation of phosphatidylserine to the outer surface of the cell membrane (Fadok et al. 1992). Apoptosis was assessed following the manufacturer's protocol in cells cultured in 48- well plates over a $24 \mathrm{~h}$ period starting on day 6 .

\section{Analysis of chondrogenic gene expression}

On days 13 and 15, C2-ceramide was added to cells cultured in six-well plates. During this period of cell maturation, the cells express established markers of the chondrocyte differentiated phenotype (Mushtaq et al. 2002). The experiment was stopped on day 17 and total RNA was extracted from chondrocytes by repeated aspiration through a 25-gauge syringe needle in $0.5 \mathrm{ml}$ Ultraspec (Biotecx, Houston, TX, USA). Following extraction with chloroform, RNA in the aqueous phase was precipitated with isopropanol and bound to RNA Tack resin (Biotecx) following the manufacturer's protocol. After washing with $75 \%$ ethanol, the RNA was eluted in $100 \mu \mathrm{l}$ ribonuclease-free water (Houston et al. 1999). For each sample, total RNA content was assessed by absorbance at $260 \mathrm{~nm}$ and purity by A260/A280 ratios, which were $1 \cdot 9-2 \cdot 0$ in all cases. All preparations were diluted to a concentration of $50 \mathrm{ng} / \mu \mathrm{l}$ and stored at $-70{ }^{\circ} \mathrm{C}$. Gene expression was analysed by semi-quantitative RT-PCR (Jefferies et al. 1998, 2000, Farquharson et al. 1999, Houston et al. 1999). Aliquots of 500 ng RNA (or an equivalent volume of water as a control) were reverse transcribed in $20 \mu \mathrm{l}$ reactions containing cDNA equivalent to $10 \mathrm{ng}$ RNA and $200 \mathrm{nM}$ gene-specific primers (Table 1) in $11 \cdot 1 \times$ PCR buffer (Jefferies et al. 2000). Primers were designed to span introns. The cycling profile was $1 \mathrm{~min}$ at $92{ }^{\circ} \mathrm{C}$ (first cycle, $2 \mathrm{~min}$ ), $1 \mathrm{~min}$ at $55^{\circ} \mathrm{C}$ and $1 \mathrm{~min}$ at $70{ }^{\circ} \mathrm{C}$. The number of cycles performed was carefully titrated to ensure that the reactions were in the exponential phase. Reaction products were analysed on $1.5 \%$ agarose gels in the presence of ethidium bromide $(250 \mu \mathrm{g} / \mathrm{l})$, and a digital image of each gel was captured using a gel documentation system (Bio-Rad Laboratories). 
Table 1 Primer pairs used for semi-quantitative RT-PCR analysis

Primer sequence

Gene

$18 \mathrm{~S}$

Collagen Type II

Collagen Type $\mathrm{X}$

Sox 9

Reverse

Forward

Reverse
Unknown, purchased commercially from Ambion ${ }^{\mathrm{a}}$

$5^{\prime}$ CACACTGGTAAGTGGGGCAAGACC $3^{\prime}$

5' GGATTGTGTTGTTTCAGGGTTCGGG 3'

5' AGGCAAGCCAGGCTATGGAA 3'

5' GCTGTCCTGGAAAGCCGTTT 3'

5'ATCTGAAGAAGGAGAGCGAG 3'

5' TCAGAAGTCTCCAGAGCTTG3'
Cycles

Product size (bp)

Forward
Reverse
20

30

35

35
488

172

583

263

${ }^{\mathrm{a}}$ Ambion, Huntingdon, Cambs, UK.

\section{IGF-I studies in ATDC5 cells}

The cells were treated with C2-ceramide $(25 \mu \mathrm{M})$ for $24 \mathrm{~h}$ in the presence of IGF-I. In further studies, the cells were treated with C2-ceramide $(25 \mu \mathrm{M})$ in the presence of IGF-I or AG1024, an IGF-I and insulin receptor blocker, $(10 \mu \mathrm{M}$; Sigma) for $24 \mathrm{~h}$ (Lee et al. 2005, Sutter et al. 2006). The diluent for AG1024 was dimethylsulfoxide (final concentration $0 \cdot 1 \%)$. Control cultures received $0 \cdot 1 \%$ dimethylsulfoxide only. The minimum concentration at which ceramide could inhibit IGF-I-induced proliferation in ATDC5 cells was examined using $\mathrm{C} 2$-ceramide concentrations between 10 and $40 \mu \mathrm{M}$ at $5 \mu \mathrm{M}$ intervals using serum-free medium.

\section{Western blotting analysis}

On day 6, ATDC5 cells were treated with C2-ceramide $(25 \mu \mathrm{M})$ for $24 \mathrm{~h}$ in serum-free medium, and then either lysed immediately (control cultures received $0 \cdot 1 \%$ ethanol only) or stimulated with IGF-I $(100 \mathrm{ng} / \mathrm{ml})$ for $10 \mathrm{~min}$ before lysis (control cultures received $0 \cdot 1 \%$ ethanol and were not stimulated with IGF-I).

Cells were lysed in PhosphoSafe extraction buffer (Merck Biosciences Ltd) containing 'Complete' protease inhibitor cocktail (Roche) according to the manufacturer's instructions. Lysates (corresponding to $25 \mu \mathrm{g}$ protein) were run on $10 \%$ Bis-Tris gels (Invitrogen) and transferred onto a nitrocellulose membrane. The membranes were blocked with $5 \%$ non-fat dry milk in Tris-buffered saline/Tween-20 (TBST; $50 \mathrm{mM}$ Tris-HCl, $300 \mathrm{mM} \mathrm{NaCl}, 0 \cdot 1 \%$ Tween-20, $\mathrm{pH} 7 \cdot 6$ ) at $4{ }^{\circ} \mathrm{C}$ overnight with gentle shaking. The membranes were probed for $1 \mathrm{~h}$ at room temperature with primary antibodies raised in rabbit (all 1:1000 dilution in 5\% milk) against phospho-Akt (ser 473), total Akt, phosphoP44/42 MAP kinase (Thr202-/Tyr204), total P44/42 MAP kinase, Phospho-SAPK/Jun N-terminal kinase (JNK) (Thr183/Tyr185), total stress-activated protein kinase (SAPK)/JNK, phospho-p38 MAP kinase (Thr180/Tyr182) and total p38 MAP kinase (Cell Signaling Technology, Beverly, MA, USA). The blots were washed $4 \times 15 \mathrm{~min}$ in TBST. The membranes were then incubated with anti-rabbit IgG-peroxidase (Cell Signalling Technology) for $1 \mathrm{~h}(1: 1000$ dilution in $5 \%$ milk). The membranes were washed, as described above, and developed using the electrogenerated chemiluminescent labeling (ECL)-plus Western Blotting Detection System (Amersham Biosciences).

\section{Immunoprecipitation of IRS-1}

ATDC5 cells were treated with C2-ceramide $(25 \mu \mathrm{M})$ for $24 \mathrm{~h}$ in serum-free medium and stimulated with IGF-I $(100 \mathrm{ng} / \mathrm{ml}$ ) for $10 \mathrm{~min}$ (control cultures received $0 \cdot 1 \%$ ethanol and were not stimulated with IGF-I). Cells were then lysed in lysis buffer $(150 \mathrm{mM} \mathrm{NaCl} ; 10 \mathrm{mM}$ Tris- $\mathrm{HCl}$ $\mathrm{pH} 7 \cdot 4 ; 0 \cdot 5 \% \mathrm{NP} 40 ; 1 \mathrm{mM}$ sodium vanadate; $0.5 \mathrm{M}$ EDTA; $0 \cdot 1 \mathrm{M}$ phenylmethylsulphonyl fluoride; $4 \mathrm{mg} / 1$ aprotinin). IRS-1 was immunoprecipitated by incubating cell lysates overnight at $4{ }^{\circ} \mathrm{C}$ with $2 \mu \mathrm{g} / \mathrm{ml}$ anti-IRS-1 antibody and $30 \mu \mathrm{l}$ protein A-Sepharose beads. Protein bound to the beads was washed four times with lysis buffer, and $10 \mu \mathrm{l}$ aliquots were run on 3-8\% Tris-Acetate gels (Invitrogen) and transferred onto a nitrocellulose membrane. The membranes were blocked as described above and probed for $1 \mathrm{~h}$ at room temperature with antiphosphotyrosine clone 4G10 and total IRS-1 antibodies (Upstate, Lake Placid, New York, USA), raised in mouse and rabbit respectively. The blots were washed $4 \times 15 \mathrm{~min}$ in TBST. The membranes were then incubated with anti-mouse IgG-peroxidase (Cell Signalling Technology) for $1 \mathrm{~h}$ (1:1000 dilution in 5\% milk). The membranes were washed and developed as described above.

\section{Organ culture}

The middle three metatarsals were aseptically dissected from 19-day-old embryonic Swiss mice. Bones were cultured at $37{ }^{\circ} \mathrm{C}$ in a humidified atmosphere of $95 \%$ air $/ 5 \% \mathrm{CO}_{2}$ in 24 well plates. Each culture well contained $300 \mu 1 \alpha-$ minimum essential medium (MEM) (Invitrogen) supplemented with $0 \cdot 2 \%$ BSA, Fraction V (Sigma); $1 \mathrm{mmol} / 1$ $\beta$-glycerophosphate (Sigma); $0.05 \mathrm{mg} / \mathrm{ml} \mathrm{L-ascorbic} \mathrm{acid}$ phosphate (Wako Pure Chemicals Ltd, Neuss, North Rhine-Westphalia, Germany); 0.05 mg/ml gentamycin and $1 \cdot 25 \mu \mathrm{g} / \mathrm{ml}$ fungizone (Invitrogen; Mushtaq et al. 2004). C2ceramide was added at a final concentration of 40, 30, 20 and $10 \mu \mathrm{M}$ for an 8-day period. Controls were treated with BSA 
carrier. In further studies, C2-ceramide was added at a final concentration of $40 \mu \mathrm{M}$ for an 8-day period, in the presence of IGF-I $(100 \mathrm{ng} / \mathrm{ml})$. The minimum concentration at which ceramide could affect metatarsal growth was examined using C2-ceramide concentrations between 0 and $40 \mu \mathrm{M}$ at $10 \mu \mathrm{M}$ intervals. In all experiments, the medium was changed every second or third day. The experimental protocol was approved by Roslin Institute's Animal Users Committee and the animals were maintained in accordance with Home Office guidelines for the care and use of laboratory animals.

\section{Morphometric analysis}

Digital images of the metatarsals were captured every second day of culture and viewed on a Nikon Eclipse TE3000 microscope (Nikon, Kingston upon Thames, Surrey, UK), using a digital camera (DS Camera Head DS-5M; Nikon). The total length of the bone through the centre of the mineralising zone was determined using image analysis software (DS Camera Control Unit DS-L1; Nikon). All results are expressed as a percentage change from harvesting length which was regarded as baseline.

\section{Statistical analysis}

All experiments were performed at least twice. General Linear Model analysis was used to assess the data. All data are expressed as the mean \pm s.E.M. of six observations within each experiment. Statistical analysis was performed using Minitab 14 (State College, PA, USA). $P<0 \cdot 05$ was considered to be significant.

\section{Results}

Proinflammatory cytokine exposure inhibits proliferation via a ceramide mechanism

TNF- $\alpha(10 \mathrm{ng} / \mathrm{ml})$ treatment of the ATDC5 chondrocyte cell line significantly reduced cell proliferation compared with control cultures (Fig. 1; 93\%; $P<0 \cdot 001$ ). To determine whether this inhibition might be mediated via an A-SMase ceramide mechanism, we assayed the effects of the A-SMase inhibitor D609 in conjunction with TNF- $\alpha$ treatment. D609 $(10 \mu \mathrm{g} / \mathrm{ml})$ significantly increased proliferation over tenfold compared with cytokine treatment alone (Fig. $1 ; P<0 \cdot 001$ ), and in the absence of TNF- $\alpha$ (Fig. 1; 84\%; $P<0 \cdot 001)$. These results suggest that TNF- $\alpha$ reduces proliferation through an A-SMase ceramide mechanism.

\section{Characterisation of the effect of C2-ceramide on ATDC5 cells}

In order to examine the effect of ceramide on cell growth, the relative contribution of altered cell proliferation, apoptosis or differentiation were assessed. In the ATDC5 cells, $40 \mu \mathrm{M}$ C2-ceramide significantly reduced cell

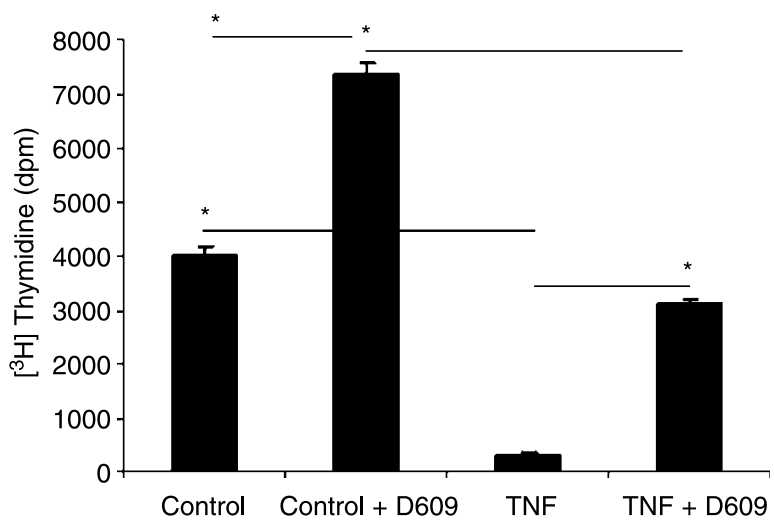

Figure 1 Effect of TNF- $\alpha(10 \mathrm{ng} / \mathrm{ml})$, D609 $(10 \mu \mathrm{g} / \mathrm{ml})$ and TNF- $\alpha+$ D609 on $\left[{ }^{3} \mathrm{H}\right]$ thymidine uptake (d.p.m.), mean +1 S.E.M., $n=6$; $* P<0 \cdot 001$ compared with control.

proliferation over a $24 \mathrm{~h}$ period (Fig. 2A). This was confirmed in further studies when thymidine uptake was corrected for protein content (Fig. 2B). Apoptosis was increased at both 40 and $25 \mu \mathrm{M}$ C2-ceramide following exposure for $24 \mathrm{~h}$ (Fig. 2C). There was no significant alteration in C2-ceramide-induced mRNA expression of markers of chondrogenesis or differentiation (sox 9, collagen II and collagen X) at all concentrations studied (Fig. 3).

\section{IGF-I studies}

The IGF-I signalling pathway is the major autocrine/paracrine regulator of bone growth. Therefore, we undertook a series of studies to examine the effects of C2-ceramide on IGF-I-induced proliferation and bone growth. The lowest concentration of C2-ceramide that inhibited ATDC5 cell proliferation following $18 \mathrm{~h}$ serum deprivation was $25 \mu \mathrm{M}$ in the presence of IGF-I (Fig. 4A). Cells exposed to C2ceramide $(25 \mu \mathrm{M})$ in the presence or absence of IGF-I for $24 \mathrm{~h}$ indicated that IGF-I alone significantly increased proliferation (Fig. 4B; $P<0 \cdot 001$ ). In the presence of IGFI, C2-ceramide induced a $68 \%$ reduction in proliferation (Fig. 4B; $P<0 \cdot 001)$. However, in the absence of IGF-I, ceramide induced a comparable $61 \%$ decrease (Fig. 4B; $P<0 \cdot 001)$.

To confirm that these effects are physiologically relevant, we tested the effects of $\mathrm{C} 2$-ceramide on bone growth using a fetal metatarsal model. The lowest concentration of C2ceramide that significantly reduced fetal metatarsal growth was $40 \mu \mathrm{M}$ in the presence of IGF-I (Fig. 5A). A 31\% reduction in metatarsal growth was observed at $40 \mu \mathrm{M} \mathrm{C2-}$ ceramide both in the presence and absence of IGF-I (Fig. 5B; both $P<0 \cdot 001$ ). In conclusion, C2-ceramide does not appear to inhibit exogenous IGF-I-induced growth plate chondrocyte proliferation or bone growth.

The effect of C2-ceramide on endogenous IGF-I-induced ATDC5 cell proliferation was examined (Fig. 4C). AG1024 

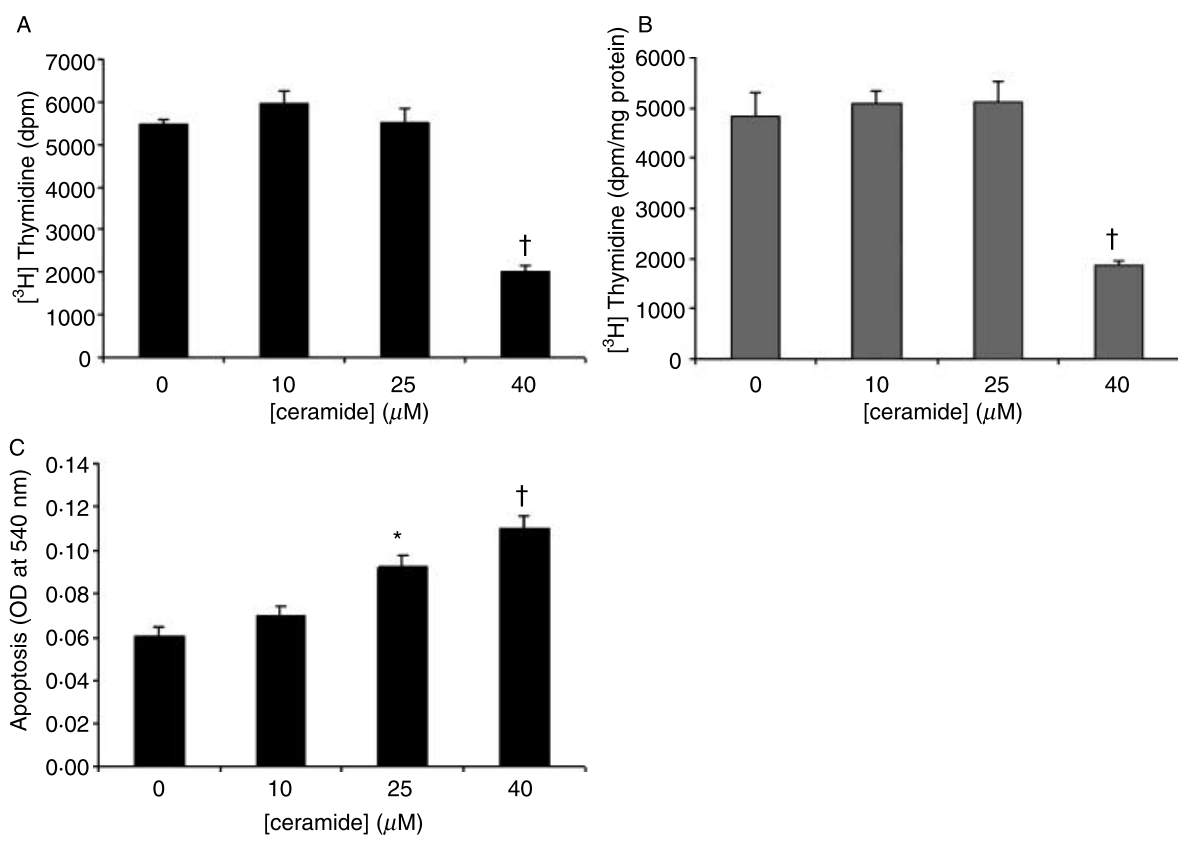

Figure 2 Effect of $\mathrm{C} 2$-ceramide $(10,25$ and $40 \mu \mathrm{M})$ on $(\mathrm{A})\left[^{3} \mathrm{H}\right]$ thymidine uptake (d.p.m.) following $24 \mathrm{~h}$ exposure; (B) $\left.{ }^{3} \mathrm{H}\right]$ thymidine uptake (d.p.m./mg protein) following $24 \mathrm{~h}$ exposure and (C) apoptosis (optical density (OD) at $540 \mathrm{~nm}$ ) following $24 \mathrm{~h}$ in ATDC5 cell culture; mean + 1 s.E.M., $n=6 ;{ }^{*} P<0 \cdot 01 ;{ }^{+} P<0 \cdot 001$ compared with control.

$(10 \mu \mathrm{M})$ reduced proliferation by $28 \%$ compared with control cells $(P<0 \cdot 001)$. C2-ceramide $(25 \mu \mathrm{M})$ significantly reduced proliferation compared with AG1024 treatment $(55 \%, P<$ $0 \cdot 001)$. C2-ceramide and AG1024 in combination further reduced proliferation compared with $\mathrm{C} 2$-ceramide alone (46\%; $P<0 \cdot 01)$. Therefore, C2-ceramide does not inhibit endogenous IGF-I-induced ATDC5 proliferation.

\section{Cell signalling}

The IGF-I-induced phosphorylation of IRS-1, Akt or P44/42 MAP kinase was not inhibited by $24 \mathrm{~h}$ C2-ceramide exposure (Fig. 6). Further, studies determined the direct effects of C2ceramide on MAPK subfamilies, which are associated with cell survival and stress stimuli. The phospho-SAPK/JNK, phospho-p38 MAP kinase or P44/42 MAP kinase expression was not altered by $24 \mathrm{~h} \mathrm{C} 2$-ceramide exposure (data not shown). Therefore, C2-ceramide does not inhibit signalling of the MAPK subfamilies or IGF-I in ATDC5 chondrogenic cells.

\section{Discussion}

Ceramide is an intracellular second messenger, whose signalling plays an important role in the regulation of cell proliferation, differentiation and survival (Kolesnick 2002, Ruvolo et al. 2002, Menaldino et al. 2003). This is the first study to demonstrate that $\mathrm{C} 2$-ceramide inhibits proliferation and induces apoptosis in growth plate chondrocytes. Ceramide has been shown to induce apoptosis in a wide range of different cell types, including pancreatic $\beta$-cells (Sjoholm 1995), cardiomyocytes (de Vries et al. 1997), astrocytes (Oh et al. 2006) and articular chondrocytes (Sabatini et al. 2000, Gilbert et al. 2004, 2006).

The partial attenuation of TNF- $\alpha$-induced inhibition of proliferation by D609, an inhibitor of ceramide synthesis, suggests that ceramide may mediate the effects of pro-inflammatory cytokines in growth plate chondrocytes. An increase in proliferation was also observed in the presence of
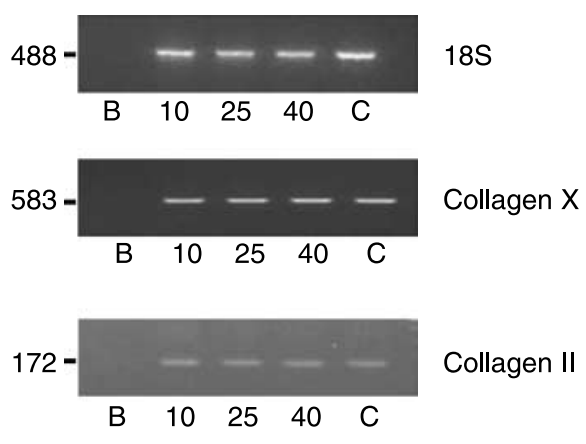

Collagen II

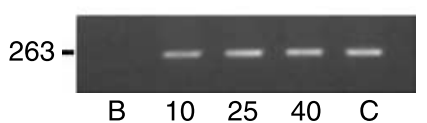

Sox 9

Figure 3 Semi-quantitative RT-PCR analysis of collagen II, collagen $X$ and sox 9 expression in ATDC5 cells following exposure to C2-ceramide at 10, 25 and $40 \mu \mathrm{M}$ compared with control (C) samples; B, blank. 

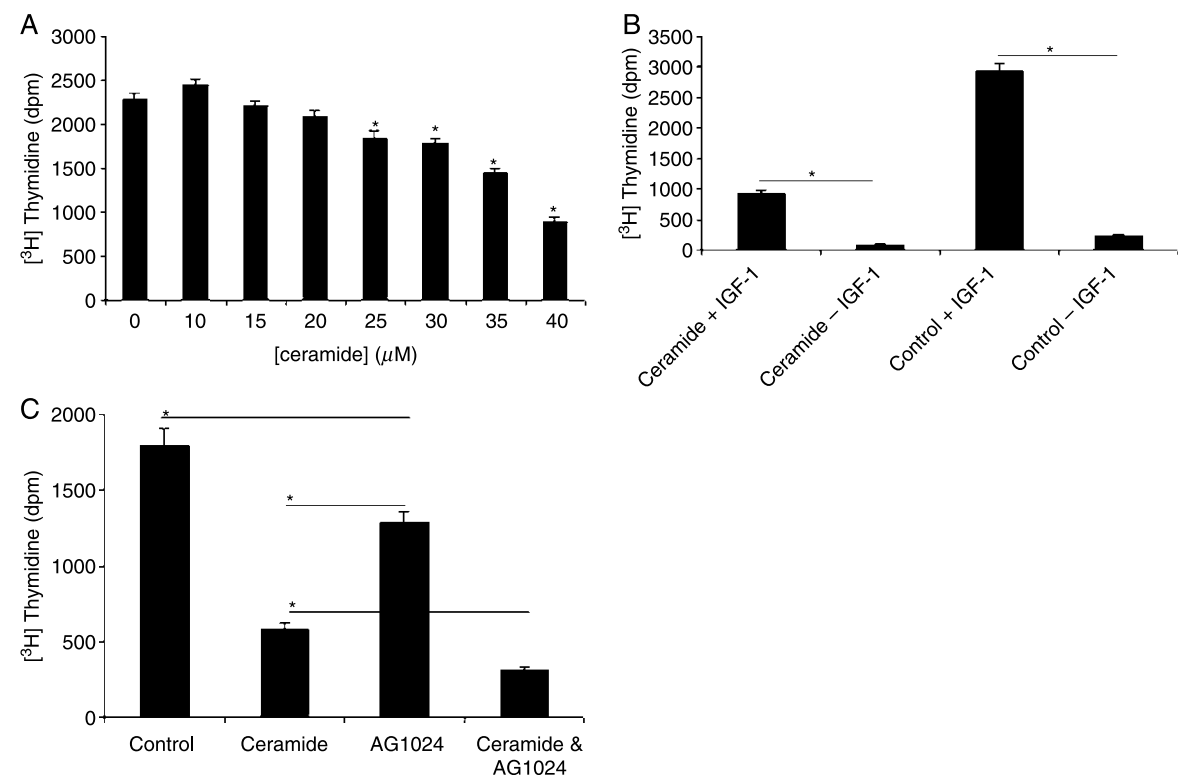

Figure 4 Effect of (A) C2-ceramide (10, 15, 20, 25, 30, 35 and $40 \mu \mathrm{M})$; (B) C2-ceramide+/-IGF $(100 \mathrm{ng} / \mathrm{ml})$ and $(\mathrm{C}) \mathrm{C} 2$-ceramide $(25 \mu \mathrm{M})$, AG1024 $(10 \mu \mathrm{M})$ and C2-ceramide + AG1024 on [ $\left.{ }^{3} \mathrm{H}\right]$ thymidine uptake (d.p.m.) in ATDC5 cells; mean +1 s.E.M., $n=6 ;{ }^{*} P<0 \cdot 001$ compared with control.

D609 in the control cells, without exogenous cytokines, suggesting that growth plate chondrocytes have an endogenous production of ceramide. Blocking this endogenous production may act as an internal regulator of proliferation.

Standardisation of $\left[{ }^{3} \mathrm{H}\right]$ thymidine uptake to protein content (Phornphutkul et al. 2006) confirms that an actual reduction in proliferation was observed following ceramide exposure, rather than solely a reduced uptake due to fewer cells through increased apoptosis. Both TNF- $\alpha$ and IL-1 $\beta$ exposure have also been reported to inhibit proliferation and induce apoptosis in ATDC5 cells (MacRae et al. 2006b), and the results of this present study now suggest that ceramide may be acting as a second messenger in both processes. Both IL-1 $\beta$ and $\mathrm{TNF} \alpha$ have also been shown to markedly reduce the gene expression of collagen II, collagen $\mathrm{X}$ and aggrecan (MacRae et al. 2006b), but in our present study ceramide did not alter the gene expression of markers of chondrogenesis and differentiation (sox 9, collagen II and collagen $\mathrm{X}$ ). This suggests that ceramide generation does not affect differentiation in growth plate chondrocytes. Therefore, ceramide production may be just one of many different pathways through which the pro-inflammatory cytokines act.

Having established that C2-ceramide inhibits proliferation and induces apoptosis, we went on to demonstrate that these effects are not mediated through the inhibition of the IGF-I signalling pathway, which is the major autocrine/paracrine regulator of bone growth (Loveridge et al. 1990). Strle et al. (2004) demonstrated that ceramide inhibits IGF-I-induced protein synthesis and differentiation in myoblasts. However, it has also been reported that ceramide can inhibit myoblast growth and differentiation in the absence of exogenous IGF-I (Meadows et al. 2000, Strle et al. 2004). This apparent discrepancy is likely to be a consequence of experimental design, and in particular the presence or absence of serum and
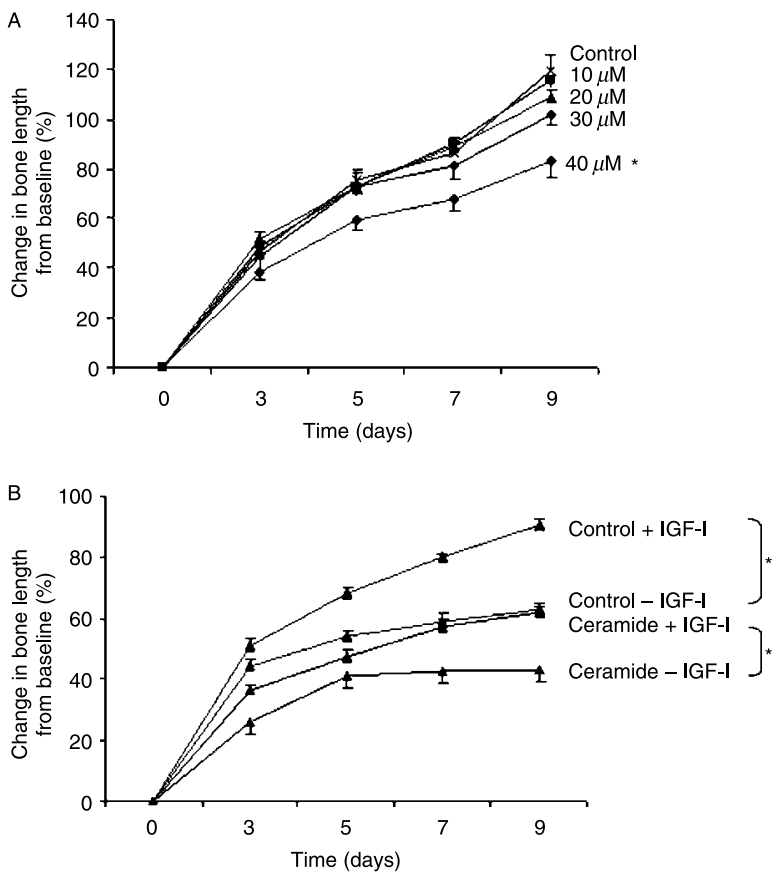

Figure 5 Effect of (A) C2-ceramide $(10,20,30$ and $40 \mu \mathrm{M})$ in the presence of IGF-I $(100 \mathrm{ng} / \mathrm{ml})$ and (B) C2-ceramide $(40 \mu \mathrm{M})+/-$ IGF $(100 \mathrm{ng} / \mathrm{ml})$ on fetal metatarsal bone growth (percentage change in bone length from baseline percentage); mean +1 S.E.M., $n=6$; ${ }^{*} P<0 \cdot 001$ compared with control. 


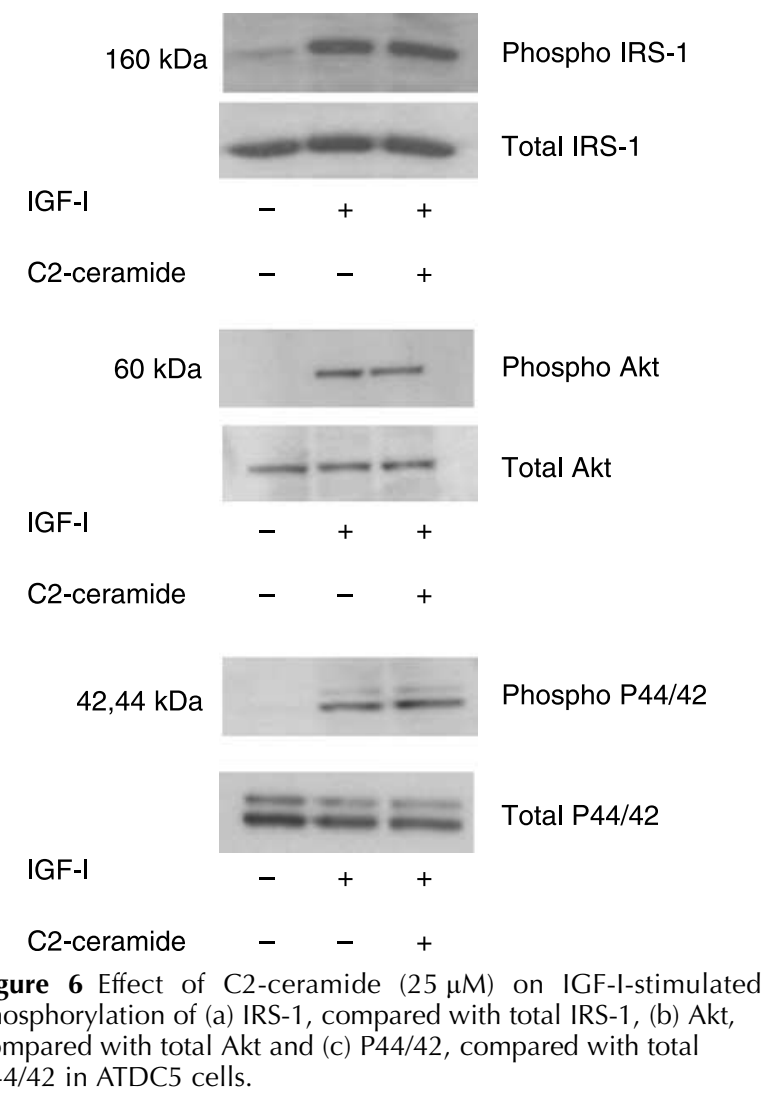

the concentration of ceramide used (Strle et al. 2004). In our experiments, the lowest concentration of $\mathrm{C} 2$-ceramide that inhibited ATDC5 cell proliferation following $18 \mathrm{~h}$ serum deprivation was $25 \mu \mathrm{M}$ in the presence of IGF-I, compared with $40 \mu \mathrm{M}$ under standard serum-containing culture conditions. This indicates that the ATDC5 cells are more susceptible to the actions of ceramide when serum deprived, and under stress.

C2-ceramide induced a comparable reduction in ATDC5 proliferation and fetal metatarsal growth both in the absence and presence of exogenous IGF-I. Furthermore, in the presence of AG1024, an IGF-I and insulin receptor blocker, ceramide was still able to inhibit proliferation. These data suggest that $\mathrm{C} 2$-ceramide is able to inhibit bone proliferation by mechanisms that are independent of IGF-I signalling, which are in agreement with the previous studies (Meadows et al. 2000, Strle et al. 2004).

Cell signalling studies confirmed that ceramide did not inhibit the IGF-I-induced phosphorylation of IRS-1, or the major downstream pathways of IRS-1; P44/42 MAP kinase and PI3 kinase (as determined by Akt phosphorylation). Previous studies have reported that ceramide inhibits IGF-Iinduced IRS-1 phosphorylation in myoblasts (Strle et al. 2004) and inhibits insulin-induced IRS-1 phosphorylation in hepatic cells (Kanety et al. 1996). However, studies in other cell types, such as adipocytes (Summers et al. 1998) and motor neuron cells (Zhou et al. 1998) have shown that ceramide does not inhibit insulin-induced IRS-1 phosphorylation. Ceramide has been shown to inhibit IGF-I-induced Akt phosphorylation in myoblasts (Strle et al. 2004) and to inhibit insulin-induced Akt phosphorlyation in adipocytes (Stratford et al. 2004) and motor neuron cells (Zhou et al. 1998). Therefore, the effects of ceramide on the IGF-I signalling pathway may depend on cell type, as well as whether stimulation is through insulin or IGF-I.

Involvement of MAPK subfamilies (P44/42 MAP kinase, c-JNK, and p38 kinase) in ceramide-induced apoptosis have been reported in various cell types, including astrocytes (Blazquez et al. 2000, Oh et al. 2006), neuronal cells (Verheij et al. 1996, Willaime et al. 2001, Willaime-Morawek et al. 2003), lung cancer-derived cells (Kurinna et al. 2004) and vascular smooth muscle cells (Loidl et al. 2004). The P44/42 MAP kinase pathway plays a major role in regulating cell growth, survival and differentiation. In contrast, JNK and $\mathrm{p} 38$ pathways are activated in response to chemical and environmental stress (Xia et al. 1995, Cobb 1999). However, our studies showed that in growth plate chondrocytes, whilst ceramide induced apoptosis, the phosphorylation of P44/42 MAP kinase, JNK and p38 kinase was not altered.

Our previous studies have shown that IGF-I plays a major role in promoting longitudinal growth in the mouse metatarsal model (Mushtaq et al. 2004). Furthermore, the growth inhibitory effect of dexamethasone was reversed in this model following exposure to IGF-I (Mushtaq et al. 2004). However, the growth inhibitory effects of TNF- $\alpha$ and IL-1 $\beta$ are only partially reversed following treatment with IGF-I (Martensson et al. 2004), suggesting that some of the effects of these proinflammatory cytokines may be IGF-I independent. Furthermore, recombinant human growth hormone therapy in children with growth retardation and chronic inflammatory disease may result in a rise in IGF-I and a cessation in further deterioration in growth (Davies et al. 1997, Bechtold et al. 2003).

However, the failure to observe a clear normalisation of growth may be explained by the possibility that the growth retardation in these children may be due to a combination of a defect in growth regulatory pathways that are IGF-I dependent and independent.

\section{Acknowledgements}

We are grateful to Miss Elaine Seawright for her contribution to the experiments. Novo Nordisk UK Ltd and the Biotechnology and Biological Sciences Research Council (BBSRC) generously supported this study. The authors declare that there is no conflict of interest that would prejudice the impartiality of this scientific work. 


\section{References}

Atsumi T, Miwa Y, Kimata K \& Ikawa Y 1990 A chondrogenic cell-line derived from a differentiating culture of AT805 teratocarcinoma cells. Cell Differentiation and Development 30 109-116.

Bechtold S, Ripperger P, Hafner R, Said E \& Schwarz HP 2003 Growth hormone improves height in patients with juvenile idiopathic arthritis: 4-year data of a controlled study. Journal of Pediatrics 143 512-519.

Blazquez C, Galve-Roperh I \& Guzman M 2000 De novo-synthesized ceramide signals apoptosis in astrocytes via extracellular signal-regulated kinase. FASEB Journal 14 2315-2322.

Cobb MH 1999 MAP kinase pathways. Progress in Biophysics and Molecular Biology 71 479-500.

Davies UM, Jones J, Reeve J, CamachoHubner C, Charlett A, Ansell BM, Preece MA \& Woo PMM 1997 Juvenile rheumatoid arthritis - effects of disease activity and recombinant human growth hormone on insulin-like growth factor 1, insulin-like growth factor binding proteins 1 and 3, and osteocalcin. Arthritis and Rheumatism 40 332-340.

Fadok VA, Voelker DR, Campbell PA, Cohen JJ, Bratton DL \& Henson PM 1992 Exposure of phosphatidylserine on the surface of apoptotic lymphocytes triggers specific recognition and removal by macrophages. Journal of Immunology 148 2207-2216.

Farquharson C, Berry JL, Mawer EB, Seawright E \& Whitehead CC 1995 Regulators of chondrocyte differentiation in tibial dyschondroplasia: an in vivo and in vitro study. Bone 17 279-286.

Farquharson C, Lester D, Seawright E, Jefferies D \& Houston B 1999 Microtubules are potential regulators of growth-plate chondrocyte differentiation and hypertrophy. Bone 25 405-412.

Gilbert SJ, Duance VC \& Mason DJ 2004 Does protein kinase R mediate TNF-alpha- and ceramide-induced increases in expression and activation of matrix metalloproteinases in articular cartilage by a novel mechanism? Arthritis Research and Therapy 6 R46-R55.

Gilbert SJ, Blain EJ, Jones P, Duance VC \& Mason DJ 2006 Exogenous sphingomyelinase increases collagen and sulphated glycosaminoglycan production by primary articular chondrocytes: an in vitro study. Arthritis Research and Therapy 8 R89.

Houston B, Seawright E, Jefferies D, Hoogland E, Lester D, Whitehead C \& Farquharson C 1999 Identification and cloning of a novel phosphatase expressed at high levels in differentiating growth plate chondrocytes. Biochimica et Biophysica Acta - Molecular Cell Research 1448 500-506.

Jefferies D, Botman M, Farquharson C, Lester D, Whitehead CC, Thorp BH \& Farquharson C 1998 Cloning differentially regulated genes from chondrocytes using agarose gel differential display. Biochimica et Biophysica Acta - Gene Structure and Expression 1396 237-241.

Jefferies D, Houston B, Lester D, Whitehead CC, Thorp BH, Botman M \& Farquharson C 2000 Expression patterns of chondrocyte genes cloned by differential display in tibial dyschondroplasia. Biochimica et Biophysica ActaMolecular Basis of Disease 1501 180-188.

Kanety H, Hemi P, Papa MZ \& Karasik A 1996 Sphingomyelinase and ceramide suppress insulin-induced tyrosine phosphorylation of the insulin receptor substrate-1. Journal of Biological Chemistry 271 9895-9897.

Kolesnick R 2002 The therapeutic potential of modulating the ceramide/sphingomyelin pathway. Journal of Clinical Investigation $1103-8$.

Kurinna SM, Tsao CC, Nica AF, Jiffar T \& Ruvolo PP 2004 Ceramide promotes apoptosis in lung cancer-derived A549 cells by a mechanism involving c-Jun $\mathrm{NH}_{2}$-terminal kinase. Cancer Research 64 $7852-7856$.

Lee CC, Huang CC, Wu MY \& Hsu KS 2005 Insulin stimulates postsynaptic density-95 protein translation via the phosphoinositide 3-kinase-Aktmammalian target of rapamycin signalling pathway. Journal of Biological Chemistry 280 18543-18550.

Loidl A, Claus R, Ingolic E, Deigner HP \& Hermetter A 2004 Role of ceramide in activation of stress-associated MAP kinases by minimally modified LDL in vascular smooth muscle cells. Biochimica et Biophysica Acta $1690150-158$.
Loveridge N, Farquharson C \& Scheven BAA 1990 Endogenous mediators of growth. Proceedings of the Nutrition Society 49 443-450.

MacRae VE, Farquharson C \& Ahmed SF 2006a The pathophysiology of the growth plate in juvenile idiopathic arthritis. Rheumatology 45 11-19.

MacRae VE, Farquharson C \& Ahmed SF $2006 b$ The restricted potential for recovery of growth plate chondrogenesis and longitudinal bone growth following exposure to pro-inflammatory cytokines. Journal of Endocrinology 189 319-328.

Martensson K, Chrysis D \& Savendahl L 2004 Interleukin-1 beta and TNFalpha act in synergy to inhibit longitudinal growth in fetal rat metatarsal bones. Journal of Bone and Mineral Research 19 1805-1812.

Mathias S, Younes A, Kan CC, Orlow I, Joseph C \& Kolesnick RN 1993 Activation of the sphingomyelin signalling pathway in intact EL4 cells and in a cell-free system by IL-1 $\beta$. Science 259 519-522.

Meadows KA, Holly JM \& Stewart CE 2000 Tumour necrosis factor-alphainduced apoptosis is associated with suppression of insulin-like growth factor binding protein-5 secretion in differentiating murine skeletal myoblasts. Journal of Cellular Physiology 183 330-337.

Memon RA, Holleran WM, Moser AH, Seki T, Uchida Y, Fuller J, Shigenaga JK, Grunfeld C \& Feingold KR 1998 Endoxin and cytokines increase hepatic sphingolipid biosynthesis and produce lipoproteins enriched in ceramides and sphingomyelin. Arteriosclerosis, Thrombosis and Vascular Biology 18 1257-1265.

Menaldino DS, Bushnev A, Sun A, Liotta DC, Symolon H, Desai K, Dillehay DL, Peng Q, Wang E, Allegood J et al. 2003 Sphingoid bases and de novo ceramide synthesis: enzymes involved, pharmacology and mechanisms of action. Pharmacological Research 47 373-381.

Mushtaq T, Farquharson C, Seawright E \& Ahmed SF 2002 Glucocorticoid effects on chondrogenesis, differentiation and apoptosis in the murine ATDC5 chondrocyte cell line. Journal of Endocrinology 175 705-713.

Mushtaq T, Bijman P, Ahmed SF \& Farquharson C 2004 Insulin-like growth factor-I augments chondrocyte hypertrophy and reverses glucocorticoidmediated growth retardation in fetal mice metatarsal cultures. Endocrinology 145 2478-2486.

Oh HL, Seok JY, Kwon CH, Kang SK \& Kim YK 2006 Role of MAPK in ceramide-induced cell death in primary cultured astrocytes from mouse embryonic brain. Neurotoxicology 27 31-38.

Phornphutkul C, Wu KY \& Gruppuso PA 2006 The role of insulin in chondrogenesis. Molecular and Cellular Endocrinology 249 107-115.

Ruvolo PP, Clark W, Mumby M, Gao F \& May WS 2002 A functional role for the B56 alpha-subunit of protein phosphatase $2 \mathrm{~A}$ in ceramide-mediated regulation of $\mathrm{Bcl} 2$ phosphorylation status and function. Journal of Biological Chemistry 277 22847-22852.

Rybakina EG, Nalivaeva NN, Pivanovich YU, Shanin SN, Kozinets A \& Korneva EA 2001 The role of neutral sphingomyelinase in interleukin1 beta signal transduction in mouse cerebral cortex cells. Neuroscience and Behavioral Physiology 31 439-444.

Sabatini M, Rolland G, Leonce S, Thomas M, Lesur C, Perez V, de Nanteuil G \& Bonnet J 2000 Effects of ceramide on apoptosis, proteoglycan degradation, and matrix metalloproteinase expression in rabbit articular cartilage. Biochemical and Biophysical Research Communications 267 438-444.

Sjoholm A 1995 Ceramide inhibits pancreatic beta-cell insulin production and mitogenesis and mimics the actions of interleukin-1 beta. FEBS Letters 367 283-286.

Stratford S, Hoehn KL, Liu F \& Summers SA 2004 Regulation of insulin action by ceramide: dual mechanisms linking ceramide accumulation to the inhibition of Akt/protein k kinase B. Journal of Biological Chemistry 279 36608-36615.

Strle K, Broussard SR, McCusker RH, Shen WH, Johnson RW, Freund GG, Dantzer R \& Kelley KW 2004 Proinflammatory cytokine impairment of insulin-like growth factor I-induced protein synthesis in skeletal muscle myoblasts requires ceramide. Endocrinology 145 4592-4602.

Summers SA, Garza LA, Zhou H \& Birnbaum MJ 1998 Regulation of insulin-stimulated glucose transporter GLUT4 translocation and Akt kinase activity by ceramide. Molecular and Cellular Biology 18 5457-5464.

Sutter AP, Hopfner M, Huether A, Maaser K \& Scherubl H 2006 Targeting the epidermal growth factor receptor by erlotinib (Tarceva) for the treatment of esophageal cancer. International Journal of Cancer 118 1814-1822. 
Tynjala P, Lahdenne P, Vahasalo P, Kautiainen H \& Honkanen V 2006 Impact of anti-TNF therapy on growth in severe juvenile idiopathic arthritis. Annals of the Rheumatic Diseases 65 1044-1049.

Verheij M, Bose R, Lin XH, Yao B, Jarvis WD, Grant S, Birrer MJ, Szabo E, Zon LI, Kyriakis JM et al. 1996 Requirement for ceramideinitiated SAPK/JNK signalling in stress-induced apoptosis. Nature $\mathbf{3 8 0}$ 75-79.

de Vries JE, Vork MM, Roemen TH, de Jong YF, Cleutjens JP, van der Vusse GJ \& van Bilsen M 1997 Saturated but not mono-unsaturated fatty acids induce apoptotic cell death in neonatal rat ventricular myocytes. Journal of Lipid Research 38 1384-1394.

Wiegmann K, Schutze S, Machleidt T, Witte D \& Kronke M 1994 Functional dichotomy of neutral and acidic sphingomyelinases in tumor necrosis factor signaling. Cell 78 1005-1015.

Willaime S, Vanhoutte P, Caboche J, Lemaigre-Dubreuil Y, Mariani J \& Brugg B 2001 Ceramide-induced apoptosis in cortical neurons is mediated by an increase in $\mathrm{p} 38$ phosphorylation and not by the decrease in ERK phosphorylation. European Journal of Neuroscience 13 2037-2046.
Willaime-Morawek S, Brami-Cherrier K, Mariani J, Caboche J \& Brugg B 2003 C-Jun N-terminal kinases/c-Jun and p38 pathways cooperate in ceramide-induced neuronal apoptosis. Neuroscience 119 387-397.

Wong SC, MacRae VE, McGrogan P \& Ahmed SF 2006 The role of cytokines in inflammatory bowel disease growth retardation. Journal of Pediatric Gastroenterology and Nutrition 43 144-155.

Xia Z, Dickens M, Raingeaud J, Davis RJ \& Greenberg ME 1995 Opposing effects of ERK and JNK-p38 MAP kinases on apoptosis. Science 270 1326-1331.

$\mathrm{Xu}$ J, Yeh CH, Chen S, He L, Sensi SL, Canzoniero LM, Choi DW \& Hsu CY 1998 Involvement of de novo ceramide biosynthesis in tumor necrosis factor-alpha/cycloheximide-induced cerebral endothelial cell death. Journal of Biological Chemistry 273 16521-16526.

Zhou H, Summers SA, Birnbaum MJ \& Pittman RN 1998 Inhibition of Akt kinase by cell-permeable ceramide and its implications for ceramideinduced apoptosis. Journal of Biological Chemistry 273 16568-16575.

Received in final form 11 July 2006

Accepted 28 July 2006 